\title{
A GEOGRAFIA DA E NA ESCOLA: CONSTRUINDO NOVAS AGENDAS DE PESQUISAS E DE LUTAS
}

\author{
Eduardo Donizeti Girotto ${ }^{1}$
}

\begin{abstract}
Resumo: Apresentamos, neste artigo, os resultados das pesquisas desenvolvidas, desde 2015, no Laboratório de Ensino e Material Didático, do Departamento de Geografia da Universidade de São Paulo, buscando compreender como, através da produção de uma outra Geografia da Escola, as políticas educacionais sob a ótica da Nova Gestão Pública têm construído um outro lugar para a Geografia na escola, que se consolida atualmente na Reforma do Ensino Médio e na Base Nacional Comum Curricular. Para tanto, analisamos duas políticas educacionais postas em prática no estado de São Paulo nos últimos anos, demonstramos a importância da análise espacial das mesmas. Com tais resultados, apontamos a necessidade de construir novas agendas de pesquisa e luta no campo do ensino da geografia, compreendo a relação intrínseca entre a Geografia como condição da existência dos fenômenos e como disciplina escolar e acadêmica.
\end{abstract}

Palavras-chave: Ensino de geografia; política educacional; dimensão espacial.

\section{GEOGRAPHY OF AND IN SCHOOL: BUILDING NEW AGENDAS FOR RESEARCH AND STRUGGLE}

\begin{abstract}
We present, in this article, the results of the research developed since 2015 in the Laboratory of Teaching and Didactic Material of the Department of Geography of the University of São Paulo, trying to understand how, through the production of another Geography of the School, educational policies under the perspective of the New Public Management has built another place for geography in the school, which is now consolidated in the High School Reform and the National Curricular Common Base. Therefore, we analyze two educational policies put into practice in the state of São Paulo in recent years, we show the importance of the spatial analysis of the same. With these results, we point out the need to construct new agendas for research and struggle in the field of geography teaching. I understand the intrinsic relation between Geography as a condition of the existence of phenomena and as a school and academic discipline.
\end{abstract}

Keywords: Geography teaching; educational politics; space dimension.

\footnotetext{
${ }^{1}$ Docente do Departamento de Geografia da Universidade de São Paulo. egirotto@usp.br Estudos Geográficos, Rio Claro, 16(2): 156-175, jul./dez. 2018 (ISSN 1678-698X) http://www.periodicos.rc.biblioteca.unesp.br/index.php/estgeo
} 


\section{INTRODUÇÃO}

Setembro de 2015. Pela mídia tradicional, a Secretaria Estadual de Educação de São Paulo apresenta projeto de reorganização escolar que prevê o fechamento de 94 unidades em todo estado e remanejamento de mais de 300 mil alunos. Novembro de 2015. Mais de 200 escolas públicas da rede estadual de Educação de São Paulo são ocupadas por estudantes, última ação na tentativa de impedir, arbitrariamente, o fechamento das escolas. Em fevereiro de 2016, são mais de 1000 escolas ocupadas em todo o país. Nestes movimentos, revelam-se Geografias em disputa, concepções e projetos de sociedade que tem, no território da escola, um dos lócus de sua realização. Nos movimentos, uma certeza se coloca: a Geografia da escola importa. E é esta a ideia que norteia este texto.

Em um momento no qual avançam políticas educacionais sob a ótica da Nova Gestão Pública ${ }^{2}$, que atingem diretamente as condições de trabalho, ensino e aprendizagem de milhares de discentes e docentes, é fundamental que a defesa da Geografia como conteúdo escolar se faça, em nossa perspectiva, a partir da crítica da Geografia da Educação e da escola propostas em tais políticas. É essencial reconhecer que, em uma lógica da gestão da escassez, em momento no qual a crise do processo de reprodução do capital se acentua, intensificando as contradições entre capital e trabalho, as políticas educacionais têm cumprindo função estratégica aos agentes hegemônicos, seja na produção de subjetividades que localizam a crise nas escolhas dos indivíduos (DARDOT \& LAVAL, 2014), seja na distribuição espacial dos equipamentos educacionais, com impactos evidentes na efetivação do direito à Educação. Para tanto, é imprescindível reconhecer a relação indissociável da Geografia enquanto condição da existência dos fenômenos da realidade e como conhecimento sistematizado, na escola e na universidade, com maior intensidade a partir do final do século XIX. Isso significa falar, ao mesmo tempo, de uma Geografia da e na Escola, dupla dimensão que tem sido disputada, constantemente, por meio de diversas políticas públicas e das lutas dos movimentos sociais.

Defendemos, portanto, neste texto, a aproximação destes dois campos de investigação como o intuito de avançarmos na construção de novas agendas de pesquisa na Geografia, que possam, em certa medida, implicar e ressignificar agendas de luta em defesa de um projeto de sociedade, Educação e escola pública para além da lógica do capital. As proposições e reflexões aqui apresentadas são resultado das pesquisas desenvolvidas, desde 2015, no Laboratório de Ensino e Material Didático, do Departamento de Geografia da Universidade de São Paulo. Em tais pesquisas, temos buscado compreender como, através da produção de uma outra Geografia da Escola, as políticas educacionais sob a ótica da Nova Gestão Pública têm construído um outro lugar para a Geografia na escola, que se consolida atualmente na Reforma do Ensino Médio e na Base Nacional Comum Curricular.

Diante destas questões, o presente texto encontra-se organizado da seguinte forma: iniciamos retomando o debate sobre as pesquisas em ensino de Geografia, buscando apresentar semelhanças e diferenças nas investigações que

\footnotetext{
${ }^{2}$ Segundo Andrade (2015, p. 631), entre os princípios da Nova Gestão Pública destacam-se: "a dissociação das funções de execução e controle; a fragmentação das burocracias e sua abertura às demandas e exigências dos usuários; a concorrência de atores públicos com o setor privado e a terceirização dos serviços; o reforço das responsabilidades e da autonomia dos níveis de execução da ação pública; a gestão por resultados e a contratação (os chamados contratos de gestão) fundadas na realização dos objetivos e da avaliação de desempenho; a normalização via padronização, das práticas profissionais baseadas em evidências e em experimentos exemplares".

Estudos Geográficos, Rio Claro, 16(2): 156-175, jul./dez. $2018 \quad$ (ISSN 1678 -698X) http://www.periodicos.rc.biblioteca.unesp.br/index.php/estgeo
} 
dialogam sobre a Geografia na e da Escola. A seguir, passamos a analisar as possibilidades de uma agenda de pesquisa, indicando temas e problemas, que podem advir deste diálogo entre as duas dimensões da Geografia aqui propostas. Por fim, problematizamos como tal diálogo já está presente na luta de diferentes movimentos, no campo e na cidade, que passaram a compreender e disputar a Geografia da escola enquanto ação fundamental para a disputa mais ampla de um outro projeto de Educação e sociedade. Além disso, assumimos que parte da crise que ora enfrentamos, é resultado da forma como temos pensado e organizado a Geografia na na universidade, cada vez mais hegemonizada pelo produtivismo e por uma lógica que coloca, no centro das preocupações, os interesses individuais do pesquisador. Sem esta capacidade de autocrítica, pouco poderemos avançar na luta pela Geografia, não como um campo de privilégios, mas como condição de realização da vida de cada sujeito social.

\section{A GEOGRAFIA COMO CONDIÇÃO E DISCIPLINA: CONSTRUINDO CAMINHOS DE DIÁLOGO}

Nas últimas décadas, o diálogo entre Educação e Geografia tem se dado, prioritariamente, por meio do debate curricular. Seja através de pesquisas que buscam compreender os processos de formação docente na área, seja pelos debates que visam reconhecer as especificidades da Geografia como conteúdo escolar, definindo rupturas e continuidades em relação aos conhecimentos geográficos produzidos na universidade, tais pesquisas consolidaram, desde o final do século XIX, aquilo que definiremos neste texto como a Geografia na Educação / Escola. Trata-se de uma concepção que afirma a importância deste conhecimento disciplinar na formação de sujeitos capazes de pensar o mundo em que vivem nas mais diferentes escalas espaço-temporais de apreensão e compreensão dos fenômenos.

No interior desta perspectiva, o diálogo entre Educação e Geografia tem sido mediado, principalmente, nas pesquisas mais recentes, pelas diferentes teorias do currículo, em suas mais diversas abordagens e concepções, uma vez que é neste campo que se colocam as principais questões acerca da relação entre as distintas dimensões do conhecimento geográfico. No decorrer da história e da epistemologia da Geografia como disciplina escolar, no Brasil e no mundo, os debates curriculares que envolvem, entre outras coisas, a compreensão dos sujeitos, processos, concepções e conflitos presentes na elaboração de documentos, diretrizes e propostas (o que pudemos verificar, recentemente, nas questões relacionadas a construção da Base Nacional Comum Curricular), ocupam o centro das pesquisas, consolidando um importante acúmulo de discussão que tem possibilitado, docentes e discentes, na escola e na universidade, compreenderem a intrínseca relação entre currículo, Geografia e sociedade.

Os resultados de tais pesquisas têm possibilitado uma ampla compreensão da Geografia como um conteúdo fundamental nos currículos da Educação básica, ao mesmo tempo em que contribuem para a construção de críticas pertinentes a forma como, muitas vezes, tal conhecimento é ensinado na escola, marcado por uma lógica conteudista que pouco ou nada dialoga com a realidade dos estudantes. Tal crítica, presente em autores e autoras deste campo desde o final do século XIX, se faz cada vez mais necessária diante de um

Estudos Geográficos, Rio Claro, 16(2): 156-175, jul./dez. $2018 \quad$ (ISSN 1678 -698X) http://www.periodicos.rc.biblioteca.unesp.br/index.php/estgeo 
momento histórico no qual se difundem, continuamente, políticas educacionais que reforçam um ensino de Geografia padronizado, seja nos conteúdos propostos, seja nas formas de ensinar, aprender e avaliar. Em nossa perspectiva, esta descontextualização da Geografia na Educação / Escola é um dos principais movimentos que contribuiu para que a mesma não seja considerada fundamental, principalmente pelos estudantes, nos currículos da Educação básica. Estamos diante, dessa maneira, de uma reinvenção da Geografia "decoreba", tão criticada, desde o início do século XX, por autores como Delgado de Carvalho, Aroldo de Azevedo e Maria Vicente da Conceição Carvalho. A vitória, em partes, desta Geografia enfadonha pode significar a derrota do direito de todos e todas ao acesso à Geografia, como conhecimento fundamental para ler e transformar o mundo em suas mais diferentes escalas espaço-temporais, justamente no momento em que tal conhecimento é tão imprescindível, como demonstra a apropriação feita do mesmo por diferentes empresas transnacionais na busca de novas frentes de valorização do capital.

Neste sentido, retomamos, neste texto, outro olhar sobre a relação entre a Geografia e a Educação que, sem negar a importância do debate curricular, busque estabelecer novas problemáticas sobre os sentidos da Educação e da escola pública no mundo contemporâneo. Trata-se de reconhecer que, além de conteúdo disciplinar, presente nos mais diferentes currículos, a Geografia é uma das dimensões fundantes da prática educativa e da existência humana. Configurase como condição de humanização, afinal, não é possível ser a- espacialmente. $E$ neste ponto faz-se necessária ressaltar que, antes de conhecimento sistematizado, a Geografia é uma condição de existência.

Paul Claval (2010) trata de tal tema, relacionando a Geografia à experiência no mundo, representada na forma como nomeamos as coisas, como organizamos a vida, como estabelecemos o contato com os outros homens e mulheres, como pensamos a nossa relação com a natureza. Esta presença cotidiana da Geografia faz com que, muitas vezes, não reflitamos sobre os seus múltiplos significados. Muitas vezes, aparece aos sujeitos como um saber de pouca importância, não compreendido como condição para a ação no mundo.

É neste sentido que é possível afirmar que a condição espacial, vinculada a esta Geografia do cotidiano, nem sempre é evidente em nossa vivência e compreensão do mundo. Muitas vezes, passamos ao largo do entendimento de que as localizações não são frutos do acaso, mas produzidas socialmente, a partir das diferentes formas de apropriação da sociedade em relação a natureza, mediadas pelo trabalho, pelos modos de produção, pela palavra, pela ação, pela política, pelas diferentes representações que construímos e são construídas acerca dos fenômenos da realidade. No decorrer da história da institucionalização da Geografia como ciência moderna, esta busca pelo entendimento da ordem das localizações esteve no centro das preocupações dos principais autores, tanto no que se refere aos conhecimentos ditos acadêmicos-universitários, quanto aqueles relacionados a Geografia escolar.

Se tomarmos, como exemplo, a obra de Delgado de Carvalho, temos uma ampla preocupação em afirmar a condição espacial dos fenômenos estudados no campo da Geografia Moderna em contraposição a outros campos científicos. Para Delgado (1925), todo pesquisador tem como objeto de investigação a realidade. $O$ que vai se alterando entre cada um dos campos científicos é o que destacamos na interpretação dos fenômenos. A especificidade do conhecimento geográfico está na capacidade de localizarmos as coisas, entendendo como se distribuem (e,

Estudos Geográficos, Rio $\quad$ Claro, 16(2): 156-175, jul./dez. $2018 \quad$ (ISSN 1678-698X) http://www.periodicos.rc.biblioteca.unesp.br/index.php/estgeo 
neste sentido, a relatividade de cada localização) e estabelecendo correlações com fenômenos em outras escalas geográficas. Estes três elementos (localização, distribuição e correlação) se constituiriam, portanto, para Delgado de Carvalho, os princípios que deveriam nortear a investigação geográfica da realidade, com o intuito de explicitar a condição espacial dos fenômenos.

No entanto, um dos elementos que Delgado de Carvalho não aborda em sua obra e assim o faz muito como consequência de sua posição epistemológica e política da Geografia, é que esta condição espacial dos fenômenos da realidade, revelada também pela ordem das localizações, é ocultada pela apropriação dos diferentes agentes do capital (empresas, Estados, órgãos transnacionais), que passam a redefinir as localizações e distribuições a partir dos interesses de ampliação dos lucros e de controle territorial. Muitas vezes agem apresentando como "naturais" esses processos de reconfiguração territorial, mediadas pelo discurso do espaço como palco das ações humanas.

Um dos principais autores que apontou para a necessidade de entendermos como os Estados e as grandes firmas nacionais, internacionais e transnacionais produzem as localizações e distribuições dos fenômenos da realidade a partir de seus próprios interesses foi Yves Lacoste (1991) ${ }^{3}$. Nele, o autor analisa como estas estratégias espaciais têm sido ocultadas da maioria da população a partir de ações que têm no ensino de Geografia (na escola básica e na universidade) lugares de realização. É neste contexto que aponta a existência de duas Geografias: a primeira, dos professores, que se apresenta para a maior parte da população como um saber desinteressado, desvinculado de qualquer interesse político, sem aplicação na realidade e que tem sido uma das formas que o saber geográfico se realiza na escola e na universidade; do outro, a Geografia dos estados-maiores, saber estratégico, essencialmente político e, por que não dizer, geopolítico, e por isso restrito a determinados grupos, que dele se apropriam para a reprodução de seus próprios interesses e privilégios.

Ao denunciar em sua obra tal dualidade, Lacoste também anuncia o potencial de um saber geográfico que, se apropriado pela população, pode significar um importante processo de (re)significação da luta cotidiana e resultar na construção, portanto, de uma consciência espacial, capaz de trazer à tona a condição geográfica dos fenômenos da realidade e da apropriação que tem sido feito da mesma pelos agentes hegemônicos do capital. Se, de um lado, a Geografia tem servido para fazer a guerra, como demonstram inúmeros exemplos do passado e do presente (do bombardeio dos diques vietnamitas feitos a partir de estudos geomorfológicos às estratégias de invasão do Afeganistão, Iraque e Síria), possui também o potencial de contribuir para um melhor entendimento da dimensão geográfica da realidade, dos diferentes interesses e agentes envolvidos e das possibilidades de ação nas diferentes escalas espaço-temporais. Tal entendimento, por sua vez, é fundamental para que os sujeitos sociais compreendam e transformem a realidade em que vivem, reconhecendo-se como sujeitos da produção da espacialidade.

Este movimento produzido na obra de Lacoste teve diferentes repercussões em todo o mundo, com importantes ações epistemológicas e políticas também no Brasil, tanto na Geografia que se ensina-pesquisa na universidade, quanto na escola. As décadas de 1970 e 1980 foram, assim, profícuas para o pensamento geográfico, com ampla produção que contribuiu no entendimento da condição espacial dos fenômenos da realidade. Neste

\footnotetext{
${ }^{3}$ Trata-se de A Geografia, isso serve, em primeiro lugar, para fazer a Guerra, lançado em 1976.

Estudos Geográficos, Rio Claro, 16(2): 156-175, jul./dez. $2018 \quad$ (ISSN 1678-698X) http://www.periodicos.rc.biblioteca.unesp.br/index.php/estgeo
} 
entendimento, o diálogo com a condição concreta do mundo e com o movimento da totalidade social se consolidou no campo científico da Geografia, em um intenso processo de renovação teórico-metodológica na qual os principais conceitos geográficos foram resignificados a luz de outros fundamentos metódicos, em especial, a dialética materialista-histórica.

Carlos (2011) discute tal conceito no interior do movimento de produção da totalidade social no modo de produção capitalista. Para a autora.

\begin{abstract}
A ideia de condição, que dá título ao livro, aponta a preocupação de pensar o fundamento da análise espacial do movimento - realizada pela Geografia -, localizando os movimentos da produção espacial como momento necessário da reprodução do humano (e do seu mundo). Essa condução torna possível uma primeira aproximação: a produção do espaço apareceria como imanente à produção social no contexto da constituição da civilização. $O$ ato de produzir é o ato de produzir o espaço - isto é, a produção do espaço faz parte da produção das condições materiais objetivas da produção da história humana. Portanto, o espaço como momento da produção social encontra seu fundamento na construção / constituição da sociedade ao longo do processo histórico como constitutivo da humanidade do homem (CARLOS, 2011, p. 17).
\end{abstract}

Concordamos com esta perspectiva e pensarmos ser fundamental compreender a condição espacial como central na constituição dos sujeitos e no próprio movimento da produção da totalidade social que, no presente momento, tem como agentes hegemônicos as grandes firmas nacionais e transnacionais que atuam em diferentes seguimentos. No entanto, a objetividade da condição espacial como necessária a existência de objetos, sujeitos e ações não significa, diretamente, a consciência desta condição. E este é, em nossa perspectiva, um dos principais desafios da Geografia na atualidade: possibilitar processos que levem os sujeitos a construírem a consciência da condição espacial de si mesmos e dos processos e agentes que constroem a totalidade social, em suas mais diferentes escalas espaço-temporais.

Tal desafio se torna ainda maior quando verificamos as implicações que o período técnico-científico-informacional, conforme as proposições de Santos (2014), traz à forma como nos relacionamos com a realidade e os outros sujeitos sociais. Com a ampliação da densidade técnica do território, através da implantação de diferentes redes de fixos (estradas, redes de fibra óptica, aeroportos) e de fluxos (de pessoas, mercadorias, informações, capitais) a relação que cada sujeito passa a ter com a realidade é cada vez mais mediada por estes diferentes objetos, formando uma efetiva tecnosfera. No entanto, como aponta Santos, tais objetos não podem ser tomados como neutros, desprovidos de estratégias e intencionalidades. Cada nova mudança técnica do território pressupõe outras formas de uso que estão definidas pelos agentes hegemônicos da geopolítica mundial, em constante tensão e articulação com os agentes de outras escalas (local, regional, nacional).

A partir destas perspectivas, defendemos, neste texto, a necessidade de compreender a Geografia da Educação e da Escola, o que significa reafirmar que a condição espaço-temporal dos fenômenos educacionais precisa ser identificada, analisada e compreendida, uma vez que a mesma implica diretamente na Geografia ensinada e aprendida na escola. Tal concepção busca dialogar com as Estudos Geográficos, Rio Claro, 16(2): 156-175, jul./dez. $2018 \quad$ (ISSN 1678-698X) http://www.periodicos.rc.biblioteca.unesp.br/index.php/estgeo 
críticas estabelecidas por José Mário Pires Azanha (2014), ainda na década de 1990, em relação ao que denominou de Abstracionismo Pedagógico, forma predominante pela qual as pesquisas e políticas educacionais vêm sendo pensadas no Brasil. Trata-se de uma lógica que concebe a escola como entidade indiferenciada, invariável espaço-temporalmente. É sobre esta concepção que têm se assentado as políticas de currículo e avaliação padronizadas que, negando a Geografia da Educação e da Escola, busca impor uma Geografia uniforme, seja nos conteúdos propostos, seja nas metodologias de ensino- aprendizagem. Esta tem sido a lógica dominante nas políticas educacionais sob a égide da Nova Gestão Pública e que se repõe, nos mesmos termos, na aprovação da BNCC.

A negação da Geografia da Educação e da Escola ou, pelo menos, uma tentativa implícita de mascará-la, ganha contornos mais terríveis quando pensamos no processo de formação socioespacial brasileiro, profundamente marcado por desigualdades. Somos o território dos genocídios, indígena, negro, passados e presentes. Configuramo-nos como lugar dos privilégios, da não realização dos direitos, o que levou Milton Santos a questionar, na década de 1980, se existiriam, de fato, cidadãos neste país.

No rastro das provocações feitas por Santos (1987), continuamos a colocar, em nossas pesquisas, tal questionamento, indagando, a todo momento: é possível pensar na cidadania sem uma distribuição equitativa dos direitos, sem a crítica a Geografia dos privilégios, sem o debate amplo sobre a produção e o uso desigual dos territórios? Tais questões são cada vez mais urgentes em um momento histórico em que uma nova concertação política amplia o processo de precarização dos direitos, reproduzindo a desigualdade territorial e produzindo novos genocídios cotidianos.

Por isso, pensar a Geografia da Educação é localizá-la no interior do processo de formação socioespacial brasileiro, relacionando-a com a crise estrutural do capitalismo que demanda cada vez menos trabalho vivo. É preciso questionar: qual o sentido da escola no limite da reprodução social? Tal crise atinge a escola e os seus sujeitos da mesma forma? O que a geografa da escola diz sobre ela, sobre os seus sujeitos, sobre os seus limites e possibilidades?

Afirmar a Geografia da Educação e da Escola é compreender que sua localização importa, não como um dado absoluto, mas como ponto em uma rede complexa de significações. É pensar sua dimensão multiescalar, nas relações que cada unidade escolar, por meio dos seus sujeitos, estabelece com outros lugares, com outras instituições, com os agentes hegemônicos do capital que têm encontrada na escola, cada vez mais, campo de disputa do projeto de sociedade. $E$, por isso, é fundamental também pensar a escola como território, permeado de conflitos, disputas, intencionalidades reveladas nas políticas educacionais, no trabalho docente, no diálogo com a comunidade do entorno, enfim, na dinâmica cotidiana que faz da escola também um ponto importante para o entendimento da sociedade contemporânea, de suas contradições e disputas.

\section{IMPLICAÇÕES: CONSTRUINDO AGENDAS DE PESQUISAS E LUTAS}

A partir das concepções apresentadas na seção anterior, temos buscado desenvolver uma agenda de pesquisas com o intuito de compreender o sentido geográfico das políticas educacionais contemporâneas, em especial, daquelas sob orientação da Nova Gestão Pública. De forma geral, tais políticas têm reproduzido Estudos Geográficos, Rio Claro, 16(2): 156-175, jul./dez. 2018 (ISSN 1678-698X) http://www.periodicos.rc.biblioteca.unesp.br/index.php/estgeo 
o abstracionismo pedagógico discutido por Azanha. Esta lógica tem cumprindo um papel fundamental de ocultação da condição espacial da prática educativa, sendo ação proposital em um país onde há uma profunda desigualdade da distribuição geográfica dos bens e equipamentos educacionais fundamentais para a garantia do direito à Educação, pensado aqui como o direito de todos e todas ao acesso, permanência e apropriação do conhecimento historicamente construído nas mais diversas abordagens.

Em nossas análises, pudemos perceber que esta lógica tem se reproduzido em diversas políticas educacionais contemporâneas no Brasil. Tomemos como exemplo a Base Nacional Comum Curricular (BNCC). Na propaganda oficial, o documento é apresentado como garantidor dos direitos de aprendizagem dos estudantes, construindo uma narrativa que aponta a padronização curricular como ação suficiente para que as desigualdades do sistema educacional brasileiro desapareçam. É importante destacar que tal discurso já foi aludido e utilizado em outros estados da federação, com especial destaque para São Paulo que, desde 2008, adota um modelo de currículo padronizado. Pelos dados disponíveis no site da Secretaria Estadual de Educação de São Paulo e sistematizados no Mapa 1, é possível perceber quea padronização curricular não produziu efeitos positivos na apropriação dos estudantes dos conteúdos de Língua Portuguesa e Matemática. Tal resultado é revelador dos limites da padronização curricular como medida garantidora do direito à Educação. Ao contrário, o que temos visto, no caso de São Paulo, é que tal discurso tem sido utilizado para dissimular a desigualdade geográfica da Educação, com profundos impactos à qualidade da Educação.
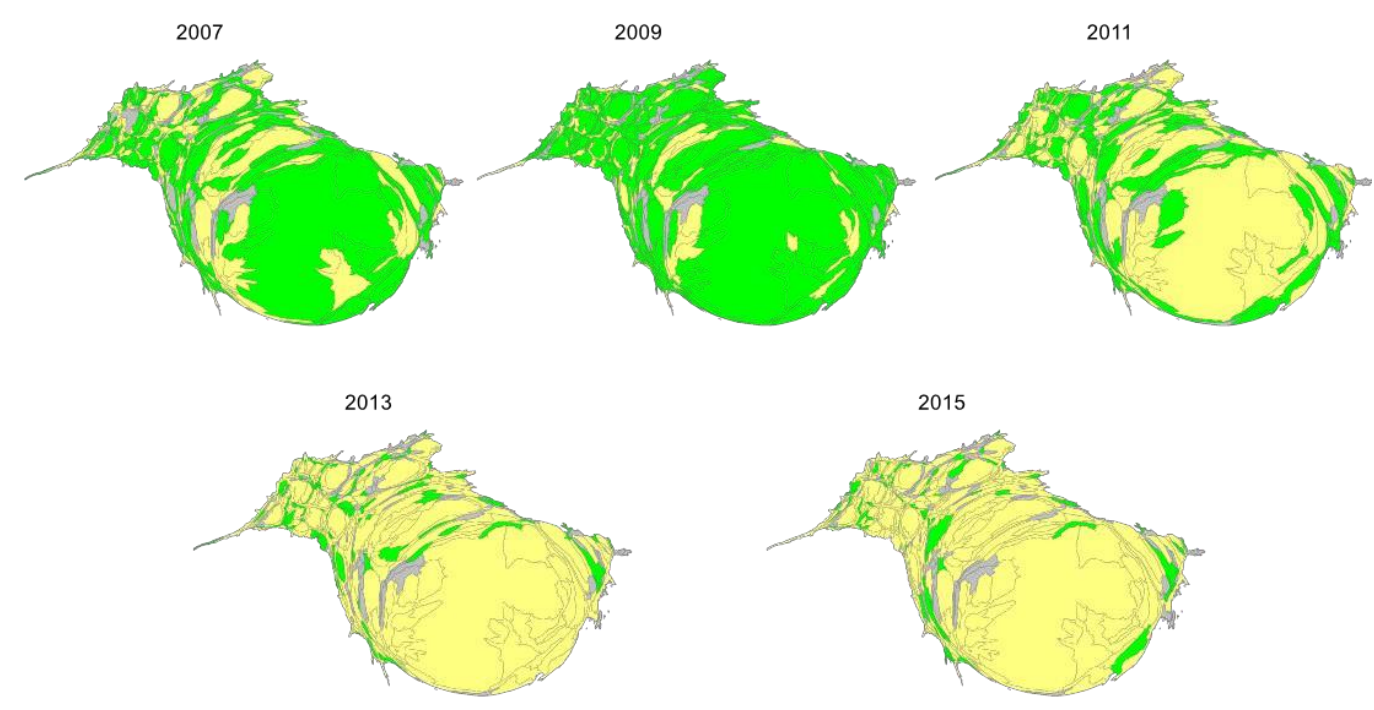

$\square$ Abaixo da meta $\square$ Atingiu a meta $\square$ Sem dado

\section{Mapa 1 - Municípios em que as escolas da rede estadual alcançaram a própria meta no IDEB ${ }^{4}$}

\footnotetext{
${ }^{4}$ Os mapas que compõem este comparativo têm em seu fundo uma anamorfose cuja métrica é o número matriculas na rede estadual por município. $\mathrm{Na}$ análise de fenômenos cuja natureza é social e, portanto, pouco relativizada pela área física do território dos distritos, com a modificação da métrica do fundo de mapa, damos representatividade espacial à quantidade de pessoas. Essa alternativa equilibra, por exemplo, o impacto visual entre os municípios com grandes áreas e poucas matrículas e os municípios fisicamente menores e com maior quantidade de matriculas, apresentando uma espacialidade Estudos Geográficos, Rio Claro, 16(2): 156-175, jul./dez. 2018 (ISSN 1678-698X) http://www.periodicos.rc.biblioteca.unesp.br/index.php/estgeo
} 
Fonte: Elaborado por PASSOS, F \& GIROTTO, E. D., a partir dos dados do SEE-SP, 2016.

Fenômeno semelhante pode ser encontrado na política de reorganização escolar proposta pelo governo do estado em 2015 e que analisamos em trabalhos anteriores. Sustentada em argumento demográfico, difundido também em publicações recentes do Banco Mundial, a proposta pressupunha o fechamento de 94 unidades escolares em todo o estado, alegando que a transição demográfica vivida pela população paulista teria produzido uma grande quantidade de salas ociosas na rede estadual, o que seria dispendioso para o Estado em momento de aludida crise econômica. Para legitimar tal argumento, no entanto, foi preciso construir uma relação não dialética entre população e território. Nesta concepção, o território aparece apenas como pano de fundo, teatro das ações humanas, pouco importando, assim, os seus usos e os impactos dos mesmos sobre a localização e distribuição dos fenômenos e processos. Ao afirmar que a população em idade escolar diminuía, apresentando dados absolutos sobre o tema, os formuladores da política buscaram ocultar um elemento fundamental da relação dialética entre população e território: sua desigualdade. Isso significa compreender que o dado absoluto da queda da população em idade escolar precisa ser relativizado a partir de recortes de classe, gênero, raça, bem como levando em consideração sua distribuição desigual no território.

A disputa da Geografia desta política educacional foi fundamental para que pudéssemos produzir dados demonstrando que o governo estadual propunha o fechamento de unidades escolares na cidade de São Paulo em áreas de aumento da população em idade escolar (Mapa 2 e 3), o que contribuiu para derrubar o principal argumento da reorganização escolar. Ao reafirmamos a Geografia da escola, pudemos demonstrar que a política educacional ora proposta estava assentada em uma concepção de território e Educação e a partir dela buscava consolidar uma reforma educacional com profundos impactos negativos sobre 0 direito à Educação de milhares de jovens paulistas.

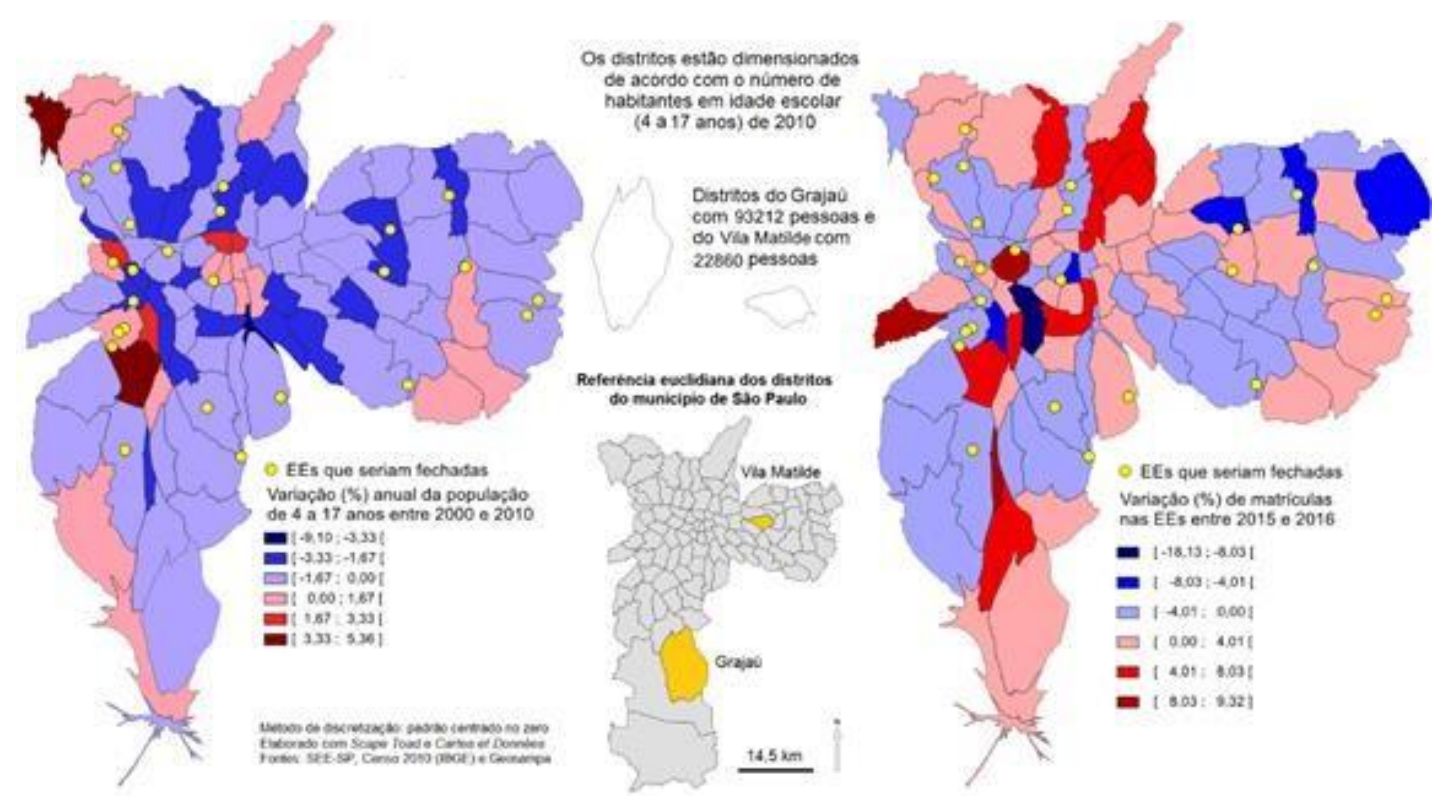

Mapa 2 e 3 - Variação demográfica (2000-2010) e de matrícula (2015-2016)

\footnotetext{
condizente aos temas investigados.

${ }^{5}$ Os dois mapas que compõem este comparativo e o próximo têm em seu fundo uma anamorfose cuja métrica é a população entre 4 e 17 anos de idade em 2010. A opção por essa métrica encontra pertinência por termos em análise Estudos Geográficos, Rio Claro, 16(2): 156-175, jul./dez. 2018 (ISSN 1678-698X) http://www.periodicos.rc.biblioteca.unesp.br/index.php/estgeo
} 
Fonte: Elaborado por PASSOS, F \& GIROTTO, E. D., a partir dos dados do IBGE (2010) e SEE-SP (2016).

Análise semelhante temos feito em relação ao Programa de Ensino Integral (PEI), colocado em prática pelo SEE-SP em 2012 e que vem sendo apresentado como exemplo de modelo bem-sucedido de política educacional. De fato, se olharmos para os resultados das escolas PEI nas avaliações padronizadas em comparação com as unidades escolares mais próximas e não- participantes do Programa (Mapa 1), temos esta impressão:

\section{PEI, cidade de São Paulo ( $\mathrm{N}=49)$}

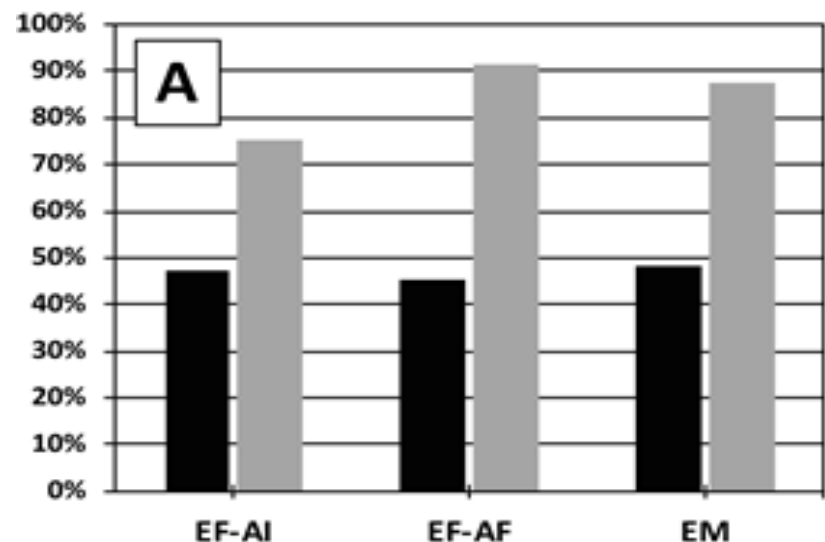

\section{Entorno PEI ( $\mathrm{N}=63)$}

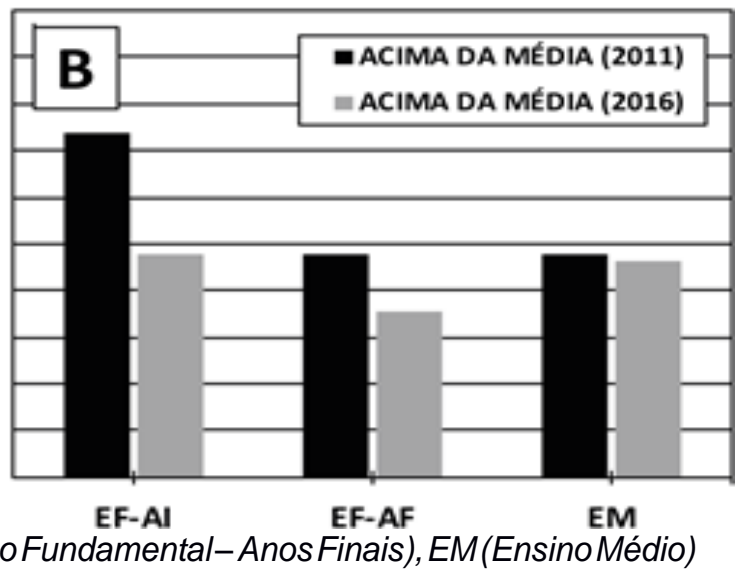

Figura 1 - Desempenho das escolas PEI (A) e do entorno (B) no IDESP ${ }^{6}$ em 2011 e 2016.

Fonte: elaborado pelos autores, a partir dos resultados das escolas e das médias do estado por ciclo divulgadas no Boletim do Idesp, disponívelem:<idesp.edunet.sp.gov.br>. Acesso em:15 out. 2017.

No entanto, quando questionamos os dados, problematizando a Geografia destas escolas (onde estão localizadas? quem são os seus sujeitos?), passamos a outro nível de interpretação que nos permite compreender as intencionalidades e estratégias implícitas da referida política educacional. $\mathrm{Na}$ análise construída, é possível perceber dois movimentos, feitos pelos gestores da política, que buscam reforçar uma Geografia das desigualdades educacionais. O primeiro consiste em escolher um conjunto de unidades escolares localizadas em áreas com melhor acesso à bens e equipamentos públicos na cidade de São Paulo (Mapa 4). Se levarmos em consideração a própria legislação estadual que prevê a matrícula de alunos em escolar até dois quilômetros de distância do local de moradia, inferimos

fenômenos (variação da população, do número de matrícula e da quantidade de classes) cuja natureza é social e, portanto, pouco relativizada pela área física do território dos distritos. Com a modificação da métrica do fundo de mapa, damos representatividade espacial à quantidade de pessoas, fato $r$ que compõe os fenômenos em questão. Essa alternativa equilibra, por exemplo, o impacto visual entre os distritos com grandes áreas e pouco povoados do extremo sul e os distritos fisicamente menores e com maior população relativa da região leste, apresentando uma espacialidade condizente aos temas investigados.

${ }^{6}$ O IDESP (Índice de Desenvolvimento da Educação do Estado de São Paulo) é um indicador de qualidade das séries iniciais $\left(1^{\mathrm{a}}\right.$ a $4^{\mathrm{a}}$ séries $)$ e finais $\left(5^{\mathrm{a}}\right.$ a $8^{\mathrm{a}}$ séries $)$ do Ensino Fundamental e do Ensino Médio. Na avaliação de qualidade das escolas feita pelo I DESP consideram-se dois critérios complementares: o desempenho dos alunos nos exames do Sistema de Avaliação de Rendimento Escolar do Estado de São Paulo (SARESP) e o fluxo escolar. O IDESP tem o papel de dialogar com a escola, fornecendo um diagnóstico de sua qualidade, apontando os pontos em que precisa melhorar e sinalizando sua evolução ano a ano. No SARESP, os alunos do $3^{\circ}, 5^{\circ}, 7^{\circ}$ e $9^{\circ}$ anos do Ensino Fundamental e da $3^{\mathrm{a}}$ série do Ensino Médio têm seus conhecimentos avaliados, anualmente, por meio de provas com questões de Língua Portuguesa, Matemática, Ciências Humanas, Ciências da Natureza e redação.

Estudos Geográficos, Rio Claro, 16(2): 156-175, jul./dez. $2018 \quad$ (ISSN 1678 -698X) http://www.periodicos.rc.biblioteca.unesp.br/index.php/estgeo 
A geografia da e na escola...

que tal escolha visa selecionar escolar com certo perfil socioeconômico de discentes (Mapa 5), ampliando assim as condições para obtenção de melhor desempenho nas avaliações padronizadas.
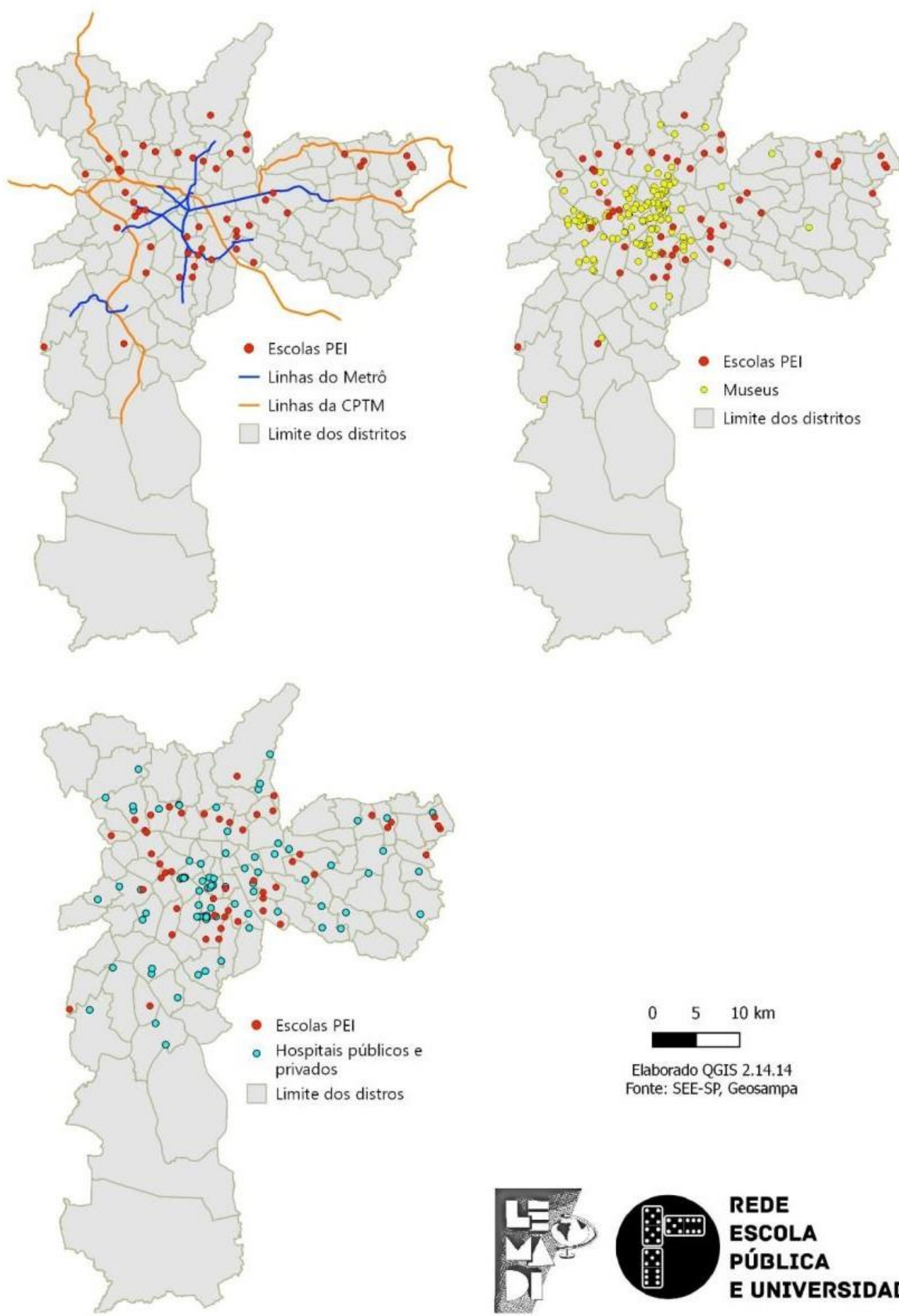

Elaborado QGIS 2.14.14 Fonte: SEE-SP, Geosampa

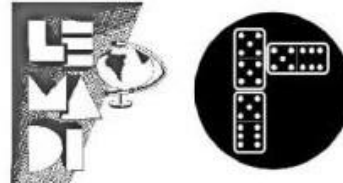

REDE

ESCOLA

PÚBLICA

E UNIVERSIDADE

Mapa 4 - Escolas PEI e distribuição dos bens púbicos e privados no município de São Paulo em 2017.

Estudos Geográficos, Rio Claro, 16(2): 156-175, jul./dez. $2018 \quad$ (ISSN 1678 -698X) http://www.periodicos.rc.biblioteca.unesp.br/index.php/estgeo 


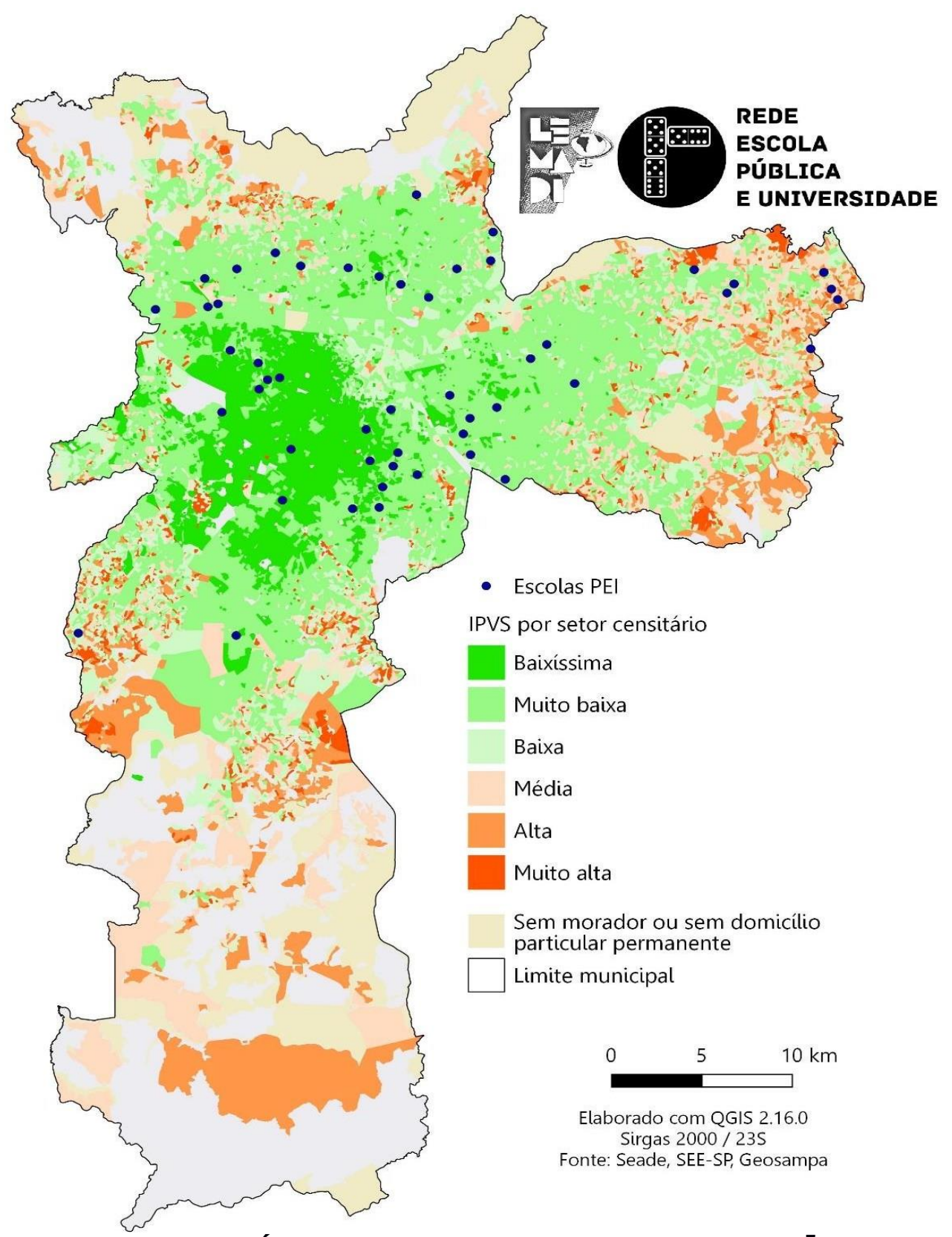

\section{Mapa 5 - Escolas PEI e Índice Paulista de Vulnerabilidade Social ${ }^{7} 7$, município de São Paulo, 2010.}

Mas este primeiro movimento não é suficiente para explicar a diferença de desempenho entre unidades escolares tão próximas. Segundo o argumento da SEE-SP, tal diferença seria resultado de modelos diversos de gestão das escolas PEI em relação as outras unidades escolares. Trata-se de um modelo de gestão assentada na lógica de mercado. Em nossa perspectiva, esse é um dos principais objetivos da política: construir

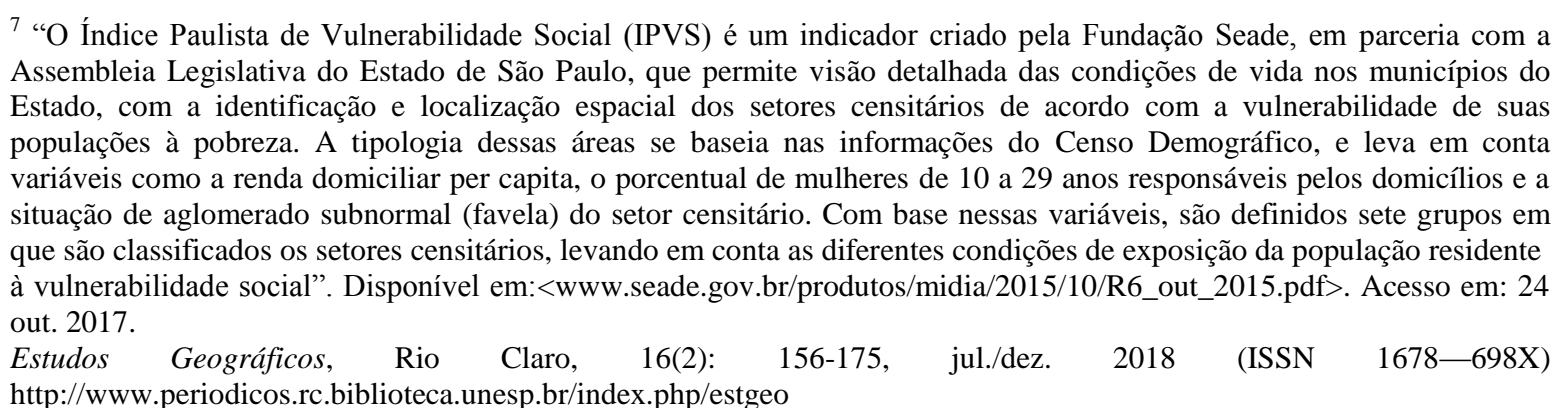


as condições de aceitação da opinião pública para justificar o processo de terceirização da gestão das unidades escolares, uma das principais pautas dos gestores neoliberais de Educação no Brasil e no mundo (vide o caso de Goiás).

No entanto, a partir das pesquisas construídas, pudemos desconstruir este argumento. Trata-se, de fato, de uma mudança de gestão que tem, no entanto, um objetivo bem claro: evitar a matrícula e a permanência, nas unidades escolares PEI, de estudantes com determinado perfil socioeconômico. Expulsos das PEI, tais estudantes migram para outras escolas da rede, em especial aquelas do entorno. Os dados compilados nas tabelas a seguir revelam este processo. Os dados se referem ao percentual de mães com ensino superior completo ${ }^{8}$ nos dois conjuntos de escolas ${ }^{9}$.

\section{Tabela 1 - Variável "escolaridade da mãe" (ensino superior completo) dos estudantes das escolas PEI - Cidade de São Paulo, 2013 e 2015}

\begin{tabular}{|l|l|l|l|l|}
\hline Escola PEI & $\begin{array}{l}\text { Ingresso } \\
\text { no PEI }\end{array}$ & $\begin{array}{l}\text { Escol. mãe } \\
(\mathbf{2 0 1 3})\end{array}$ & $\begin{array}{l}\text { Escol. mãe } \\
(\mathbf{2 0 1 5})\end{array}$ & Var. \\
\hline Ayres de Moura Prof. & 2013 & $11 \%$ & $17 \%$ & $+55 \%$ \\
\hline Carlos Maximiliano Pereira dos Santos & 2013 & $13 \%$ & $25 \%$ & $+92 \%$ \\
\hline Casimiro de Abreu & 2014 & $9 \%$ & $13 \%$ & $+44 \%$ \\
\hline Isabel Princ. & 2014 & $13 \%$ & $10 \%$ & $-23 \%$ \\
\hline Maria Ribeiro Guimarães Bueno Profa. & 2014 & $13 \%$ & $23 \%$ & $+77 \%$ \\
\hline MMDC & 2014 & $13 \%$ & $29 \%$ & $+123 \%$ \\
\hline Olga Benatti Profa. & 2014 & $14 \%$ & $28 \%$ & $+100 \%$ \\
\hline Oswaldo Aranha & 2014 & $8 \%$ & $12 \%$ & $+50 \%$ \\
\hline Raul Pilla Dep. & 2013 & $5 \%$ & $16 \%$ & $+220 \%$ \\
\hline Reinaldo Ribeiro da Silva Dr. & 2014 & $8 \%$ & $21 \%$ & $+163 \%$ \\
\hline Teotônio Alves Pereira & 2014 & $7 \%$ & $9 \%$ & $+29 \%$ \\
\hline & & $10 \%$ & $18 \%$ & $+\mathbf{7 8 \%}$ \\
\hline
\end{tabular}

Fonte: elaborado pelo autor, a partir dos questionários socioeconômicos do Saeb (2013; 2015).

\footnotetext{
${ }^{8}$ Em revisão da literatura sobre o tema, Alves e Soares (2009) assumem o nível socioeconômico como um construto teórico não diretamente observado, apontando que além do nível de escolaridade da mãe, o estrato ocupacional e o rendimento seriam as variáveis que melhor representariam o nível socioeconômico de indivíduos pertencentes a uma comunidade escolar. Por conta da ausência de dados em relação às outras duas variáveis apontadas pelos autores, trabalhamos nesta análise apenas com a "escolaridade da mãe".

${ }^{9}$ Nas análises da mudança do perfil socioeconômico dos estudantes dos dois conjuntos de escolas, selecionamos as unidades com oferta de anos finais do ensino fundamental, e que entraram no Programa entre 2012 e 2014. Essa escolha resulta do fato de que, desde 2013, a SEE-SP, não tem aplicado o questionário socioeconômico para pais e alunos durante o Saresp, sendo que o Índice de Nível Socioeconômico da Escola (INSE), criado pela própria SEE-SP em 2010, não tem sido atualizado desde então. Isso dificulta o processo de acompanhamento das mudanças socioeconômicas ocorridas nas comunidades escolares o que, em nossa perspectiva, seria fundamental para o adequado acompanhamento dos impactos da referida política pública. Com isso, não é possível avaliar a mudança do perfil socioeconômico em todas unidades escolares PEI com os dados disponibilizados pela SEE-SP.

Estudos Geográficos, Rio Claro, 16(2): 156-175, jul./dez. $2018 \quad$ (ISSN 1678-698X) http://www.periodicos.rc.biblioteca.unesp.br/index.php/estgeo
} 
Tabela 2 - Variável "escolaridade da mãe" (ensino superior completo) das escolas regulares mais próximas das escolas PEI e com oferta do mesmo ciclo - Cidade de São Paulo, 2013 e 2015

\begin{tabular}{|c|c|c|c|c|}
\hline Escola & pla PEI mais próxima & $\begin{array}{l}\text { col. } \\
(2013)\end{array}$ & mãe col. $\underset{(2015)}{\text { mãe }}$ & Var. \\
\hline Pio Telles Peixoto Prof. & Ayres de Moura Prof. & $16 \%$ & $15 \%$ & $-6,3 \%$ \\
\hline Raul Cortez & $\begin{array}{l}\text { Carlos Maximiliano } \\
\text { Pereira dos Santos }\end{array}$ & $9 \%$ & $13 \%$ & $+44,4 \%$ \\
\hline Afrânio Peixoto & Casimiro de Abreu & $22 \%$ & $12 \%$ & $-45,5 \%$ \\
\hline Raul Fonseca & Isabel Princ. & $9 \%$ & $7 \%$ & $-22,2 \%$ \\
\hline Júlio Ribeiro & 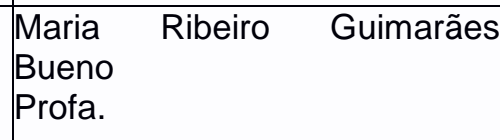 & $9 \%$ & $8 \%$ & $-11,1 \%$ \\
\hline Plínio Barreto & MMDC & $14 \%$ & $11 \%$ & $-21,4 \%$ \\
\hline Mário Casassanta Prof. & Olga Benatti Profa. & $16 \%$ & $13 \%$ & $-18,8 \%$ \\
\hline $\begin{array}{l}\text { Napoleão de Carvalho } \\
\text { Freire Prof. }\end{array}$ & Oswaldo Aranha & $7 \%$ & $16 \%$ & $+128,6 \%$ \\
\hline Jose de San Martin & Raul Pilla Dep. & $12 \%$ & $7 \%$ & $-41,7 \%$ \\
\hline Anhanguera & $\begin{array}{l}\text { Reinaldo Ribeiro da } \\
\text { Silva Dr. }\end{array}$ & $9 \%$ & 0 & $-100 \%$ \\
\hline \multirow[t]{2}{*}{$\begin{array}{l}\text { Roldão Lopes de Barros } \\
\text { Prof. }\end{array}$} & Teotônio Alves Pereira & $8 \%$ & $8 \%$ & 0 \\
\hline & & $12 \%$ & $10 \%$ & $-16,0 \%$ \\
\hline
\end{tabular}

Fonte: elaborado pelo autor, a partir dos questionários socioeconômicos do Saeb (2013; 2015).

Enquanto nas escolas PEI se constata um aumento do número de mães com ensino superior completo entre 2013 e 2015 (variação positiva), ocorre o inverso em praticamente todas as escolas regulares do entorno. Além disso, chama atenção a intensidade da variação, que em algumas escolas PEI ultrapassa $100 \%$, chegando a $220 \%$ na EE Deputado Raul Pilla. Essa mudança no perfil socioeconômico dos estudantes das escolas PEI não guarda, obviamente, qualquer relação com taxas de crescimento de mulheres com ensino superior completo no País. Os gestores da política esperam, contudo, que a alteração do perfil socioeconômico dos estudantes resulte em melhor desempenho nas avaliações padronizadas. Trata-se de uma política por e para resultado, a qualquer custo.

Esta mesma constatação foi feita em relatório do Tribunal de Contas do Estado de São Paulo (TCE-SP) em 2015, indicando que 1 em cada 6 estudantes

Estudos Geográficos, Rio $\quad$ Claro, 16(2): 156-175, jul./dez. $2018 \quad$ (ISSN 1678-698X) http://www.periodicos.rc.biblioteca.unesp.br/index.php/estgeo 
matriculadas em escolas PEI solicitavam transferência nos primeiros meses de aula. Em entrevistas realizadas durante o processo de pesquisa com professores, estudantes e gestores de algumas escolas PEI esta gestão com foco nos resultados e na exclusão ficou evidente. Trata-se, portando, de mais um caso de política educacional que, ocultando a Geografia da escola, busca produzir outra Geografia, privilegiando certos alunos, excluindo muitos outros, ampliando, assim, a perversidade do sistema educacional paulista e brasileiro.

Dessa forma, temos desenvolvido uma agenda de pesquisas, aqui apresentada de forma sucinta, com o intuito de problematizar a relação indissociável entre a Geografia da e na escola. No entanto, para além da busca de uma agenda de pesquisa intra-universidade, que só resultaria, em nossa perspectiva, no reforço da lógica produtivista que tem buscado hegemonizar o espaço da universidade nos últimos anos, importa-nos saber as possíveis implicações desta agenda de pesquisa no interior de uma agenda mais ampla de lutas em defesa da Geografia, da escola pública e na busca de construção de um outro projeto de sociedade.

Trancafiada na sala de aula, a Geografia como disciplina corre o risco de desaparecer. Como linhas no currículo lattes, na Universidade corre séria possibilidade de implosão. É na relação dialética como condição, conteúdo e prática social que reside a potência da Geografia que fazemos e são estas problemáticas que buscaremos enfrentar na parte final deste texto.

\section{AFINAL, A GEOGRAFIA IMPORTA?}

Nos últimos meses, um espectro ronda a comunidade geográfica brasileira. Trata-se do medo da retirada desta disciplina dos currículos de Ensino Médio da Escola Pública, como resultado da reforma apresentada pelo Ministério da Educação no final de 2016 e aprovada pelo congresso em fevereiro de 2017. Tal ameaça tem levado inúmeras instituições de pesquisa, de graduação e pósgraduação, a manifestarem preocupação com as possíveis implicações desta retirada, principalmente no que se refere a possibilidade de fechamento de cursos de graduação e de investimentos na pós-graduação.

Tal posicionamento forte de tais entidades se contrasta com o silêncio das mesmas nos últimos anos, em especial, acerca da importância da Geografia enquanto disciplina escolar e de um certo menosprezo dos cursos de formação de professores, sempre vistos como de menor importância na hierarquia do campo científico. Tal situação, aparentemente contraditória, revela um processo de longo prazo que marca a história da formação deste campo científico no Brasil. Sem o entendimento deste processo, pouco conseguiremos avançar no debate e na defesa da importância da Geografia como disciplina na educação básica. Tal importância não pode se caracterizar, em nossa perspectiva, como uma defesa interdisciplinar, mais preocupada com a manutenção de nossos cargos, seja na escola ou na universidade. Se, de fato, faz sentido defender a Geografia, sua importância deverá ser analisada a partir da contribuição deste conhecimento, de suas linguagens, conceitos e instrumentos, na formação de sujeitos capazes de compreender e transformar o mundo contemporâneo.

Por isso, perguntamos: a Geografia importa? Tal questionamento se desdobra em muitos outros: o que ganhamos de capacidade de leitura, interpretação e transformação do mundo com a mediação do conhecimento geográfico? O que perdemos? Que conhecimentos foram acumulados no decorrer

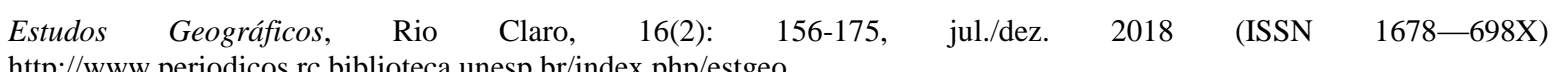


da história da Geografia como campo científico que nos ajudam a entender a sua importância no mundo contemporâneo? A quem pertence à Geografia?

Enquanto campo de conhecimento sistematizado, a Geografia possuiu mais de um século. Seu processo de institucionalização é marcado por uma série de disputas políticas e epistemológicas diretamente vinculadas a formação do Estado Nacional Burguês e a consolidação do modo de produção capitalista na Europa. Por isso, a Geografa nasce próxima do poder, sustentando e fornecendo informações fundamentais para o processo de imperialismo na África, Ásia, Oceania e América Latina. Mas esta é uma das formas de contar a história da Geografia. É preciso dizer que, naquele mesmo momento, outros geógrafos, como Elisee Reclus, defendiam uma Geografia que rompesse com a lógica da ciência como processo de conquista do outro, de desenvolvimento civilizacional. Interessa, a Reclus, uma Geografia que leve ao outro, não para conquista-lo, mas para encontrar a unidade na diversidade, reconhecendo que existe uma relação fundamental entre a terra e os homens e mulheres, em cada um dos lugares do planeta, que nunca é plenamente capturada, em qualquer projeto totalitário de sociedade. Por isso também Reclus não acredita no progresso como uma espiral única. São inúmeras espirais que nascem de lugares múltiplos e que podem, de repente, se encontrar. Como afluentes de um rio, que nascem e correm simultaneamente, sem conhecer a existência uns dos outros, podem, em algum momento, se encontrarem no leito principal, e produzirem a força necessária para romper as inúmeras barragens que impedem o seu fluxo natural.

Por isso, é preciso fugir das falsas dicotomias pelas quais a história desta ciência tem sido contada: entre Geografia física e humana, entre Geografia regional e geral, entre possibilismo e determinismo, entre Geografia francesa e alemã. Tais dicotomias não nos ajudam a entender que, como toda forma de conhecimento, a Geografia tem lugar central no debate sobre qual sociedade queremos. E, antes de ser conhecimento sistematizado, é condição da existência que extrapola qualquer leitura dicotômica. Tal compreensão pressupõe o entendimento do papel desempenhado pela universidade e seus sujeitos na produção de um discurso competente sobre a Geografia. Colocada no centro do projeto da ciência moderna, a universidade, de forma predominante, a partir do século XIX, se arrogou o direito de dizer o que é o que não considerado conhecimento legítimo.

Mas é preciso afirmar: a universidade é um dos lugares em que o conhecimento geográfico é produzido. Não é o único. $E$ isso precisa ser dito, porque parte da crise que agora enfrentamos está diretamente relacionada com aquilo que a Geografia virou, de forma predominante, na universidade. Segundo Foucault (2005), a formação da ciência moderna, no século XIX, sob a égide do Positivismo, significou um amplo processo de disciplinamento, sustentado, na ordem do discurso. Por esta ordem, o lugar de fala é mais importante do que o conteúdo da fala. Neste processo, as universidades cumpriram papel fundamental ao definir quais são os conhecimentos, sujeitos e lugares legítimos no interior de um campo científico, reforçando a centralidade da universidade na desqualificação de todos os outros saberes e conhecimentos que não fossem universitários, em mais uma das etapas da conquista do outro.

Tal processo ganha novos contornos a partir do momento em que a universidade se subordina a lógica neoliberal de gestão, com maior intensidade na década de 1990. Neste processo, a universidade, voltada para si, caminha para a implosão, naturalizando e internalizando lógicas neoliberais como se fossem suas:

Estudos Geográficos, Rio Claro, 16(2): 156-175, jul./dez. $2018 \quad$ (ISSN 1678-698X) 
disputas por bolsas, por ego acadêmico, inúmeras formas de delinquência (produção de artigos em série, cooptação de trabalhos alheios, em especial dos orientandos, etc.). Centrada em si mesma, a Geografia na universidade foi se afastando da Geografia do mundo, dos homens e mulheres em sua vida cotidiana.

Por isso, produzimos teses, dissertações e artigos que quase ninguém lê. Temos milhares de publicações no lattes, mas precisamos, toda semana, explicar, no almoço de família, o que fazemos para aquele tio chato, para o moço na padaria, para alguém no transporte público. Encastelada, a Geografia na universidade, perde a sua potência e se torna uma técnica, com um fim em si mesmo, opção mais barata para as empresas em tempo de crise. Em tempos mais prósperos, nos quais as bolsas produtividade, pagas em dia, os estágios de pós-doc no exterior, os eventos amplamente financiados, nos davam a sensação de habitar e participar, em outro lugar, do processo colonial de produção do conhecimento, a crítica a está lógica era tomada como infundada, resultante de inveja de quem não tinha chegado lá. No momento em que os cofres se fecham e os patrões decidem o que é ou não ciência no país, voltamos nosso olhar ao espelho e descobrimos que a Geografia que fazemos está diretamente relacionada a nossa formação socioespacial. Resta a dúvida: ainda há condições de resistir?

As respostas para a pergunta anterior pressupõem o entendimento da crise em suas diferentes escalas de produção. Em um momento no qual as contradições inerentes ao modo de produção capitalista se ampliam, assentadas na necessidade cada vez menor de trabalho vivo decorrente de um intenso processo de racionalização burocrática e tecnológica de produção que eliminou milhares de postos de trabalho em todo o mundo, a escola pública não pode se tornar mais um lugar de administração da pobreza. Se assim o fizer, correrá o risco de implodir, de ver seu esfacelamento diante da incapacidade de administrar uma crise que não é apenas sua, mas de um projeto de sociedade cada vez mais desigual.

Diante desta situação de esgarçamento de qualquer possibilidade de pacto social, de um futuro apreendido como caos, de uma percepção do tempo histórico como eterna repetição, de uma filosofia de vida marcado pela busca do prazer a qualquer custo, pelo atentado contra si e contra todos, o que resta à escola e a Geografia? No tempo em que uma parcela cada vez maior de homens e mulheres se tornou desnecessária, qual o sentido da Geografia que se ensina e aprende? Em nossa perspectiva, as respostas a estas perguntas precisam ser construídas colocando novamente em diálogo a Geografia com conteúdo disciplinar e como condição da existência. Isso significa dizer que a potência da escola-universidade continua a residir em sua dimensão de território, lugar do encontro, da reunião, da partilha presencial de sonhos, ideias e conflitos. Esta potência, que se materializou de forma mais intensa nos processos de ocupação de escola, está presente no trabalho cotidiano de muitos docentes e discentes em salas de aulas espalhadas por aí. Está no sonho do projeto coletivo de tantas escolas-universidades e movimentos que leram a si como lugares de produção de um outro projeto de sociedade, de uma outra Geografia menos desigual, violenta e racista.

Quando se compreendem como território, a escola-universidade, por meio dos seus sujeitos, se entendo como inacabada, como condição e não apenas produto. Como projeto, desejo, pulsão. Seus sujeitos passam a compreender aquilo que os une, a Geografia que os atravessa, os desafios que se colocam na labuta diária de ser homem e mulher em um mundo que se quer cada vez mais desumano. Lendo a Geografia de si mesmos, professores e alunos vão construindo a Geografia que se aprende e ensina, conectando e articulando a

Estudos Geográficos, Rio $\quad$ Claro, 16(2): 156-175, jul./dez. $2018 \quad$ (ISSN 1678-698X) http://www.periodicos.rc.biblioteca.unesp.br/index.php/estgeo 
potência da Geografia como condição e conteúdo.

Nesta nova lógica, não há espaço para os currículos padronizados, para avaliação em larga escala, para a gestão para e por resultados, para o gerencialismo-produtivismo, enfim, para todos os processos que buscam introjetar nos sujeitos as subjetividades necessárias para a reprodução do capital ou, pelo menos, para a não compreensão da inerente crise. Apropriados da Geografia como condição e conteúdo, aos poucos, docentes e discentes, podem produzir uma outra escola-universidade, outros lugares, outro mundo, permeados por experiências de solidariedade, pela igualdade de direitos, pela diversidade de ser e sentir. E em cada uma destas experiências, produzida no território, outras formas de ser escola-universidade, expressão sincera dos sujeitos, sonho coletivo e resistência contínua.

Por isso, continuamos a concordar com a análise construída por Lacoste em 1976: a Geografia é um saber-poder, estratégico e por isso cada vez mais apropriado no mundo contemporâneo, seja pelos estados-nacionais, seja pelas firmas transacionais. As diferentes formas de inserção do saber-geográfico na lógica de reprodução do capital (geomarketing, logística, SIGs, etc.), revelam a sua centralidade no mundo contemporâneo. Acrescentamos às análises de Lacoste, a compreensão de Michael Young sobre o currículo, identificando que a crítica aos conhecimentos dos poderosos não pode significar a negação da necessidade de apropriação dos conhecimentos poderosos. Fazer a crítica a Geografia como um conhecimento branco, patriarcal, eurocêntrico é uma parte do processo, mas não pode significar dizer que tal conhecimento pertence apenas aos homens brancos e europeus. A potência do conhecimento geográfico está nesta constante provocação de olhar para o mundo, reconhecendo a dimensão espacial dos fenômenos, expresso nas suas localizações, distribuições, correlações, em múltiplas escalas. Há que se afirmar: a Geografia é um conhecimento necessário, mas não suficiente para ler o mundo. Como necessário, é preciso reconstruí-lo e ressignificá-lo a todo o momento, reconhecendo sua potência e o direito de todos e todas a produzirem, expressarem e transformarem, pela Geografia, o mundo em que vivem.

Para que avancemos, é preciso voltar ao começo, ressignificando o que até aqui produzimos, desenterrando os mortos, enterrando outros, para que, reencontrando a terra, possamos afirmar a potência da Geografia da vida que explode em muitos lugares simultaneamente. Os conceitos, que antes eram propriedade exclusiva da acadêmica, vão ganhando outros sentidos na luta. São reapropriados pelos seus sujeitos e ganham vida, novamente, quando defrontados com a realidade. Estão vivos nos movimentos quilombola, nas mães de maio, no movimento cultural da periferia, nas lutas indígenas, no MTST, no MST. Em cada um destes movimentos, a Geografia da vida é reafirmada, ressignificada, produzindo transformação na Geografia da escola-universidade que, acovardada, muitas vezes, tem medo de se olhar no espelho. Mas é preciso ter coragem em tempos como esses. Não é possível calar frente a tanto genocídio.

O desafio consiste em encontrar a Geografia como uma luta comum. Encontrar, nas palavras de Milton, aquilo que nos une, de construir um mundo onde caibam tantos mundos. Voltamos ao rio. Estamos a sua margem. Banhamos em sua água. É preciso decidir para onde ir. Isolada, pouco produzem as águas. É na força de sua unidade, das águas de múltiplas cores que produzem uma tonalidade universal, que encontramos a potência da Geografia que carregamos.

Nesta Geografia retomada, neste movimento de feitura do mundo e de si,

Estudos Geográficos, Rio Claro, 16(2): 156-175, jul./dez. $2018 \quad$ (ISSN 1678-698X) http://www.periodicos.rc.biblioteca.unesp.br/index.php/estgeo 
os vínculos fundantes de nossa humanização podem ser retomados (dos homens e mulheres entre si, com a natureza, com o trabalho, com o amor, com a vida). $E$ com eles, reinscreve-se no mundo a escola-universidade como um ponto em uma rede de significados, tecida a tantas mãos, com tantas cores e gestos.

É a Geografia desta nova escola-universidade que nos interessa.

É por ela que lutamos.

É esta a Geografia que importa!

\section{REFERÊNCIAS}

ALGEBAILE, E. Escola pública e pobreza no Brasil. Rio de Janeiro: Lamparina, 2009.

AZANHA, J. M. P. Uma ideia de pesquisa educacional. São Paulo: Edusp, 2011. BOURDIEU, P. Efeitos delugar. In: Petrópolis: Editora Vozes, 1999. pp. 159 - 166. et al. A miséria do mundo. 3를 Edição.

BRASIL. Plano Nacional de Educação. Brasília: MEC, 2014. CARLOS, A. F. A. A condição espacial. São Paulo: Contexto, 2011.

CARVALHO, D. de. Methodologia do Ensino Geographico. São Paulo: Francisco Alves, 1925.

CHAUÍ, M. Cultura e democracia. $12^{\circ}$ edição. São Paulo, Cortez, 2007,360 páginas.

CLAVAL, T. Terra dos Homens. São Paulo: Contexto, 2010.

CAVALCANTI, L. de S. Geografia, Escola e construção do conhecimento. Campinas: Papirus, 2001.

DARDOT, P.; LAVAL, C. A nova razão do mundo. 1a edição. São Paulo: Boitempo, 2014.

FOUCAULT, M. A ordem do discurso. 20ํecição. São Paulo: Loyola, 2010.

. Em defesa da sociedade. São Paulo: Martins Fontes, 2005. FREIRE, P. Cartas ao Professores. Estudos Avançados. oㅜ 42. São Paulo. 2001. FRIGOTTO, G. A produtividade da escola improdutiva. 17ª edição. São Paulo: Cortez, 2000.

FUNDAÇÃO SEADE. Índice Paulista de Vulnerabilidade Social. São Paulo: SEADE, 2010.

GIROTTO, E. 2016. A Dimensão espacial da escola pública: leituras sobre a reorganização da rede estadual de São Paulo. Educação \& Sociedade, Campinas, v. 37, no 137, p. 1121-1141, out./dez. 2016.

GIROTTO, E. ; PASSOS, F.; CAMPOS, L.; OLIVEIRA, J. A geografia da Estudos Geográficos, Rio Claro, 16(2): 156-175, jul./dez. $2018 \quad$ (ISSN 1678-698X) http://www.periodicos.rc.biblioteca.unesp.br/index.php/estgeo 
reorganização escolar: uma análise espacial a partir da cidade de São Paulo. Educação temática digital, v. 19, 2017.

HARVEY, D. Cidades rebeldes. São Paulo: Martins Fontes, 2014.

LACOSTE, Y. A Geografia, isso serve, em primeiro lugar, para fazer a guerra. $3^{\text {a }}$ edição. Campinas, SP: Papirus, 1993.

LAVAL, C. A escola não é uma empresa. 1a edição. Londrina: Editora Planta, 2004.

LEFEBVRE, H. O direito à cidade. São Paulo: Documentos,1969.

LIBÂNEO, J. C. O dualismo perverso da escola pública brasileira: escola do conhecimento para os riscos, escola de acolhimento social para os pobres. Educação e Pesquisa. São Paulo, v. 38, 2012, p. 13-28.

PEREIRA, L. A escola numa área metropolitana. Faculdade de Filosofia, Ciências e Letras, Universidade de São Paulo, 1967.

SANTOS, M. O espaço do cidadão. 4aㅡ ed. São Paulo: Nobel, 1987.

SANTOS, M. A natureza do espaço. São Paulo: Edusp, 2014.

SÃO PAULO (Estado). Diretrizes do Programa de Ensino Integral. São Paulo: SEE- SP, 2012.

SÃO PAULO (Estado). Secretaria da Educação. Modelo de gestão de desempenho das equipes escolares: Ensino Integral. Caderno do Gestor. São Paulo. Imprensa Oficial, SE, 2014.

ROCHA, G. O. R. da; "Uma breve história da formação do professor(a) de Geografia no Brasil. Terra Livre, São Paulo, n. 15, p. 129-144, 2000.

RECLUS, E. O Homem e a Terra. Progresso. São Paulo: Imaginário, 2014.

SPÓSITO, M.P. A ilusão fecunda. São Paulo: Hucitec, 1993.

. O povo vai à escola. São Paulo: Loyola, 1984.

TEIXEIRA, A. Educação não é privilégio. 1ํe edição. São Paulo: Nacional, 1968.

Artigo submetido em: 13/06/2018

Aceito para publicação em: 04/09/2018

Publicado em: 14/12/2018

Estudos Geográficos, Rio Claro, 16(2): 156-175, jul./dez. $2018 \quad$ (ISSN 1678 -698X) 